\title{
DOES TRADITIONAL CONFLICT RESOLUTION LEAD TO JUSTICE? - THE MATO OPUT IN NORTHERN UGANDA
}

\author{
by Patricia Bako*
}

\section{Introduction}

It has been nearly 22 years since the start of war in northern Uganda, waged by the Lord's Resistance Army (LRA) under the leadership of Joseph Kony. Kony started this war with the spiritual and traditional belief in the need to defend the Acholi people from the National Resistance Movement (NRM), led by Yoweri Museveni, who took over power in 1986 from the Acholi general Tito Okello.

In this war, thousands of people have lost their lives and many others have been adducted. Some have been living in camps for many years. As a result of the conflict, and peace agreements which seemed not to yield any results, the Ugandan government on 16 December 2003 referred the issue of the LRA to the International Criminal Court (ICC), accusing the commanders of war crimes and crimes against humanity. When the investigation was initiated in January 2004 by the ICC at the request of Uganda, the local cultural and religious leaders immediately wanted the ICC investigation to be stopped, claiming that they would deal with the LRA rebel leaders in the 'Acholi way', using the local traditional justice system, with the aim of restoring the community and bringing lasting peace. ${ }^{2}$

On 13 October 2005 the ICC issued warrants of arrest to the top five commanders. ${ }^{3}$ The commanders included Joseph Kony, Vincent Otti, Okot Odhiambo, Dominic Ongwen and Rasak Lukwiya, who is now deceased. Before these indictments were issued there was a lot of debate on whether these commanders should be tried by the ICC or the traditional justice system. This led to the passing of the Amnesty

* LLM student, University of Pretoria.

1 Leaders preferred to deal with the issue by using traditional justice rather than the ICC so as to achieve reconciliation and justice.

2 'Acholi leaders in the Hague to meet ICC over the LRA probe' IRIN News 15 March 2005.

3 ICC 'Warrant of Arrest Unsealed Against Five LRA Commanders' www.icc-cpi.int/ pressrelease/114.html (accessed 5 March 2009). 
Act in 2000.4 'Amnesty' in the Amnesty Act means pardon, forgiveness, exemption, or discharge from criminal prosecution or any other form of punishment by the state. Amnesty is declared in respect of any Ugandan who at any time since 26 January 1986 engaged in, or is engaging, in war or armed rebellion against the government of the Republic of Uganda. 5

However, the people of northern Uganda have resorted to the traditional way of conflict resolution through the mato oput ritual, and the local population prefer this system to the one that the ICC will apply to ensure that justice is achieved. It is important to note that this ritual is performed only among the Acholi people. The question may be posed: what happens to other tribes in the northern part of the country who have also suffered as a result of this conflict? Will they benefit from this traditional ritual practice in that they will be able to forgive the perpetrators and reconcile with them? Will they see this as a form of justice being achieved? Can this ritual be relied on to achieve justice as an alternative to ICC trials? This article will address some aspects of the mato oput ritual and discuss whether justice could be achieved through this traditional method of conflict resolution.

\section{Comparison of the two conflict resolution mechanisms}

We have to understand our culture and know what kind of people we are. We are the kind that are willing to accept other people's mistakes without pointing fingers? Are we the kind of people who can confess truthfully and forgive wholeheartedly? ${ }^{6}$

When a conflict occurs, it can be dealt with either locally or internationally. In Uganda, there are four different systems for conflict resolutions in place. Firstly, there is Uganda's domestic judicial system, and in particular the War Crimes Division that has been set up in the High Court of Uganda. Secondly, there is the international justice system in the form of the ICC in that it has issued arrest warrants for the top rebel leaders. Thirdly, there is the Amnesty Act, which allows the rebels who denounce the rebel activity to come out and not to be prosecuted. Lastly, a traditional justice system, the mato oput, used by the Acholi people as a way to resolve

$4 \quad$ P Ongea 'Understanding the amnesty process in Uganda: Implications of the proposed amendments to the Amnesty Act and the International Criminal Court investigations' Uganda Human Rights Commission workshop 5 October 2004).

5 Chapter 294 of the Amnesty Act of 2000.

6 Paramount chief David Onen Akan cited in Liu Institute for Global Issues and the Gulu District NGO Forum 'Roco wat I Acoli: Restoring relationships in Acholi-land: Traditional approaches to justice and reintegration' http://www.ligi.ubc.ca/ sites/liu/files/Publications/JRP/15Sept2005_Roco_Wat_I_Acoli.pdf September 2005 (accessed 3 April 2009). 
conflict. Some of the people in Uganda argue that non-traditional justice systems will have a negative impact on the peace process in northern Uganda. On the other hand, some people prefer the nontraditional justice system as a means to achieve peace. ${ }^{7}$ This article will examine the arguments in favour of and against non-traditional conflict resolution and will endeavour to establish which one holds the most promise for the country's future.

\subsection{The main features of non-traditional conflict resolution mechanisms}

The three non-traditional conflict resolution systems are: Uganda's formal justice system (War Crimes Division), the international justice system and the Amnesty Act. All of them emphasise retribution by punishment as a way of achieving justice. ${ }^{8}$ The ICC issued warrants against the top leaders of the LRA only. This approach leaves a gap as there are many more perpetrators. Therefore there is arguably a need for other means to be used to achieve justice. The ICC's intervention in northern Uganda has been met with some criticism. For example, it is seen as imposing an idea of retributive justice which clashes with the traditional idea of restorative justice. ${ }^{9}$ In addition to the above, the people in northern Uganda are opposing the Rome Statute despite the fact that it is meant to serve the interest of the victims, the people of northern Uganda. ${ }^{10}$ According to this view, the Acholi victims want reconciliation and forgiveness to be achieved through the traditional mechanism and not the ICC.

\subsection{The main features of the traditional conflict resolution mechanism}

The mato oput as a way of conflict resolution has the aim of forgiveness and reconciliation. The Acholi people believe in the world of the living dead and this has an important role in the way they see justice and reconciliation. The Acholi culture considers justice as a means of restoring relations and thus it is restorative in nature. According to Chief Rwot David Onen 'the wounds of the war will be

7 P Tom 'The Acholi traditional approach to justice and the war in northern Uganda' http://www.beyondintractability.org/case_studies/acholi_traditional_ approach.jsp?nid=6792(accessed 3 April 2009).

8 J Ocen 'Can traditional rituals bring justice to northern Uganda' http:// www.ligi.ubc.ca/?p2=/modules/liu/news/view.jsp\&id=289 (accessed 3 April 2009).

9 K Southwick 'Investigating war in northern Uganda: Dilemmas for the International Criminal Court’ (2005) 1 Yale Journal of International Affairs 113. 
healed if the Acholi practise their traditional guiding principles'. ${ }^{11} \mathrm{He}$ further noted the following as being the guiding principles: 'do not be a trouble maker'; 'respect'; 'sincerity'; 'do not steal'; 'reconciliation and harmony'; 'forgiveness'; 'problem solving through discussion'; and 'children, women, and the disabled are not to be harmed in war'. ${ }^{12}$ These principles emphasise the idea of living with each other in peace and harmony.

Mato oput is a ritual performed among the Acholi people as a way to bring reconciliation and justice among the northern people of Uganda who have suffered as a result of the conflict in the region. Mato oput means drinking the bitter root.

The process involves: the guilty acknowledging responsibility; the guilty repenting; the guilty asking for forgiveness; the guilty paying for compensation; and, finally, the guilty being reconciled with the victim's family through sharing the bitter drink mato oput. The bitterness of the drink symbolises the psychological bitterness that existed in the minds and consciousness of the people in the conflict.

Mato oput is performed between two clans - the one is the clan of the perpetrator and the other clan that of the victim. ${ }^{13}$ It is performed after a mediated process has brought together two families and their clans. The offender accepts responsibility and then asks for forgiveness. The perpetrator's and the victim's family then share the root drink from a calabash. Its main purpose is to recall and bury the bitterness of the soured relationship. ${ }^{14}$ The two clans later agree on what compensation will be paid by the whole offending clan to the clan of the victim. The clans have unwritten laws on what has to be paid as compensation but it is according the gravity of the crime committed. The ritual is held as a way of promoting reconciliation between the two clans and the ceremony is said to last for the whole day.

One of the aims of the mato oput ritual is to achieve restorative justice that involves victims, perpetrators, survivors and the community as a whole, coming together to be reconciled. This justice system aims at solving the problem and achieving harmonious community relations. ${ }^{15}$ Its main characteristic is community participation that brings together the victim and the perpetrator and

11 USAID 'Acholi youths and chiefs addressing practices of the Acholi culture of reconciliation' (2005) http://www.nupi.or.ug/pdf/Youth_ChiefConference Report15-6-05.pdf (accessed 3 April 2009).

12 As above.

13 EK Baines 'The haunting of Alice: local approaches to justice and reconciliation in northern Uganda' (2007) 1 International Journal of Transitional Justice 91-114.

14 B Afako 'The traditional drink unites Ugandans' Focus on Africa Magazine (29 September 2006).

5 n 1 above. 
restores rights that have been violated. ${ }^{16}$ It is interesting to note that the Acholi people consider the ritual to bring true healing, which the formal justice system cannot. In a human rights magazine, Bishop Ochola, who lost his wife to an LRA landmine, was quoted as saying: 'Real Justice is not punishment. Real justice is not killing someone because someone has killed your child, because now you're becoming a killer just like him or her'. ${ }^{17}$ Traditional justice, he said, offers a different route: 'we are not going to kill you. We're going to give you back your life. That's different. Truth, mercy, justice, and peace must stand together'. ${ }^{18}$ This illustrates how traditional conflict resolution views justice. To the Acholi people reconciliation and future peace in the community seems to be the major emphasis. However, there is no mention of punishment. Formal justice should be applied alongside traditional conflict resolution if justice is to be achieved.

\section{Advantages and disadvantages of the two conflict resolution systems}

\subsection{The non-traditional conflict resolution mechanism}

The most important advantage of the non-traditional conflict resolution system is that it will cater for a large group of people - not only the Acholi people. Considering Uganda's diversity of cultures, this system is appealing.

It emphasises finding a guilty party in a conflict and retribution is a major element. Its aim is to punish the offender without looking at the future incorporation of the offender into the society. The system encourages the person to deny responsibility as he knows that once he accepts, punishment will follow.

Non-traditional conflict resolution prosecutions are perpetratororiented. The prosecutions attempt to be a form of reparation for past injustices, but it gives little attention to the victims who should be healed from the injustices they suffered. ${ }^{19}$ In addition to the above, it can lead to re-victimisation since criminal proceedings involve cross-examination and formalities, which makes the court room a hostile environment for the victims, resulting in humiliation and renewed trauma for the victims. ${ }^{20}$

16 JY Katshung 'Mato oput versus the International Criminal Court in Uganda' www.pambazuka.org/eng/category/comment /27403 (accessed 4 March 2009). http://www.ligi.ubc.ca/?p2=/modules/liu/news/view.jsp\&id=289 (accesed 4 March 2009).

18 AS Sussman 'The difficulties of ending war' Inthefray (1 July 2007).

19 D Bloomfield et al (eds) Reconciliation after violent conflict: A handbook (2003) 104.

20 As above. 
Furthermore, the ICC and the War Crimes Division are considered to be biased. For example, the ICC is seen as being in favour of the Ugandan government, considering the fact that it became involved in the conflict resolution at the request of Museveni. Also, the bias was intensified when the ICC limited the indictment to only the LRA, sparing the Uganda People's Defence Force (UPDF). This was contested by different groups. The Refugee Law Project (RLP) and Human Rights Watch who argued that the UPDF had also committed war crimes like the LRA. ${ }^{21}$ Turning to the War Crimes Division in the High Court, the bias is evident from the fact that UPDF soldiers will not be prosecuted by this division. ${ }^{22}$ All this shows that nontraditional conflict resolution has it own weaknesses. The question still remains as to which system should be used to ensure that justice is achieved by all those who were affected by the conflict.

\subsection{The traditional conflict resolution mechanism}

On the one hand the mato oput system encourages a person to admit guilt while at the same time it allows the person back into society, thus aiming at restorative justice between the victims and perpetrators.

On the other hand, the mato oput does not distinguish between the crimes that were committed, such as crimes against humanity and war crimes, and other crimes - it deals with all crimes and offences without any differentiation. The crimes that were committed by the LRA included cutting off hands, breasts, lips and ears of individuals, abduction of civilians, children and recruiting child soldiers. ${ }^{23}$ The lack of distinction clearly undermines the gravity of the different crimes. The mato oput should adopt the method used by the Gacaca Courts as there is a need to categorise crimes and delineate which crimes may be dealt with under the ritual. It should not be taken that all crimes that were committed by the LRA and UPDF fall within the jurisdiction of the mato oput.

\section{Can Justice be achieved through this ritual?}

It is important to take note of the fact that this ritual is only for the Acholi people. However, Uganda is a country with different tribes having their own cultures. Although the conflict happened mostly in

21 KP Apuuli 'The ICC arrest warrants for the Lord Resistance Army leaders and the peace prospects for northern Uganda' (2006) 4 Journal of International Criminal Justice 185-186.

22 T Bouwknegt 'Uganda war Crimes court excludes soldiers from trial' http:// static.rnw.nl/migratie/www.rnw.nl/internationaljustice/icc/Uganda/080918 uganda-redirected (accessed 24 March 2009).

n 2 above. 
the North, it is not only the Acholi people who were affected by the war. Various people were affected by the conflict in different ways. The Madi, Langi, Iteso and many others have their own ways and rituals to achieve justice, and they have also been affected by the war. For example, the Langi have kayo cuk, which involves slaughtering a bull. The Iteso kill a bull and smear its blood on the parties involved to resolve the conflict. The Madi have the tolu ritual, which involves a cleansing ceremony similar to that of found in Judaism. ${ }^{24}$ It becomes even more complicated for other people who do not come from northern Uganda, such as people from the central, eastern and western side. Will they consider the mato oput ritual as a way of achieving justice for those who were affected by the conflict? There is a great possibility that the other ethnic groups or tribes will not consider justice to have been achieved by this ritual because they all have different ways of achieving it.

A lesson can be drawn from the Gacaca court where traditional justice was a success. Rwanda is a country that has mainly two ethnic groups, the Tutus and Hutus. It is easier to achieve traditional justice such a society. If the mato oput is to be more effective and meaningful even to the non-Acholi people, then it should be implemented at national level but not at regional level - then probably the other ethnic groups will consider it as a mechanism to achieve justice.

Mato oput cannot be seen as a way of achieving justice if the diversity of the people is taken into account. As much as this ritual is practised among the Acholi, there is a need to have a balance between the traditional and non-traditional justice systems if the interests of the other groups as a whole are to be considered.

Furthermore, the conflict in northern Uganda did not occur only in Uganda but it spread to other countries such as southern Sudan and the Congo as the rebels usually fled from Uganda. The rebels committed war crimes and crimes against humanity in these countries. Should the mato oput also be applicable to other countries that were affected by the conflict? Will justice be achieved in these countries if only the traditional justice system is used?

In addition to the above, there is a need to categorise the crimes and establish which ones can be dealt with under the mato oput. Take for example the Gacaca court where there is a categorisation of the crimes that it can deal with and those it can't. In terms of article 15 of the Organic Law, ${ }^{25}$ the first category consists of organisers, farmers of genocide, planners, and those who committed crimes against humanity. The second category consists of those people who 
committed murder and culpable homicide. The third consists of people who committed serious attacks without the intent to cause death. The fourth category consists of those who committed offences against property. ${ }^{26}$

The first category is excluded from the Gacaca courts and falls under the jurisdiction of the national courts. Therefore, not all crimes should be dealt with under the mato oput. Crimes were committed during the conflict in northern Uganda by the LRA and the UPDF that should not be dealt with by the ritual. For example, the UPDF committed crimes including rape, torture, physical abuse and the killing of civilians in Internally Displaced People camps. ${ }^{27}$ Given the gravity of the crimes, they should be dealt with either under the ICC (in the case of the rebel leaders) and the national courts (for LRA and UPDF soldiers). Emphasis should not only be on the mato oput but there should rather be an integration of both the traditional and nontraditional justice system. Crimes that are of less gravity should be dealt with through the mato oput ritual and those that are more serious by the ICC or the War Crimes Division of the national courts. In addition, other tribes with different cultures should be encouraged to practise their own way of achieving reconciliation and justice.

Another argument is that mato oput was originally designed to deal with crimes or offences that were committed among the Acholi people, and not for war crimes and crimes against humanity. In this light mato oput should not be used for such crimes because it undermines justice in a larger spectrum. It should rather be used for offences among others such as theft or the destruction of property that occurred during the war.

Furthermore, even though the ritual is considered to be a method of reconciliation, it should not always be taken at face value. When a person comes back to the community to confess the crime that he or she committed during the conflict, the person will not necessarily be accepted back with ease because there will always be some form of resentment and stigmatisation, which makes the whole process superficial. As one of the returned, Jacqueline Auma said that 'we go through the ceremony and we are told that we have been forgiven. But the truth is people can never forget what we have done. People still call me a killer and a few of my peers will not even talk to me'. ${ }^{28}$ This illustrates that this ritual cannot completely lead to justice and this calls for a non-traditional justice system to come into play alongside this ritual.

Mwenifumbo 'Eradicating delay in the prosecution of crimes of genocide in Rwanda through Gacaca courts: will any form of justice do?' (2007) 13 East African Journal of Peace and Human Rights 311-320.

Amnesty International 'Uganda: Amnesty Internation report' (2003)

'Uganda: Traditional ritual heals communities tom apart by war' IRIN 9 June 2005. 


\section{Conclusion}

The main objective of this article was to establish whether the use of the mato oput ritual is in itself enough to lead to justice and reconciliation. Considering the diversity of the people who have been affected by the conflict, it is important to re-think how this ritual on its own will lead to justice in northern Uganda. Despite the existence of the non-traditional conflict resolution mechanisms in the country, they also have problems associated with them. Therefore the mato oput ritual should still be practised alongside the other nontraditional conflict resolution mechanisms to ensure a balance that can lead to justice. 